\title{
Evidence of membrane lipid oxidation of spray-dried Lactobacillus bulgaricus during storage
}

\author{
P. Teixeira, H. Castro and R. Kirby \\ Escola Superior de Biotecnologia, Universidade Católica Portuguesa, Porto, Portugal
}

\begin{abstract}
P. TEIXEIRA, H. CASTRO AND R. KIRBY. 1996. Membrane fatty acids of Lactobacillus
bulgaricus were analysed by gas-liquid chromatography before and after spray drying. The ratio unsaturated/saturated fatty acids decreased following spray drying, indicating the formation of lesions in cellular lipid-containing structures. The same method was used to analyse membrane lipids of Lact. hulgaricus during storage. Similarly the ratio of unsaturated/saturated fatty acids in dried cells decreased further during storage in air, presenting evidence of lipid oxidation after prolonged storage. The mechanisms of cell death during storage in the dried state are still unknown, but from these results and those presented in the literature, it seems evident that lipid oxidation and survival during storage may be related.
\end{abstract}

\section{INTRODUCTION}

The development of concentrated cultures for inoculating the production vat directly has eliminated many of the problems customarily involved in preparing and maintaining starter cultures in the dairy plant. Since the culture concentrates can be evaluated and standardized for activity before shipment to the processor, it should be possible to produce consistently high quality dairy products (Gilliland 1976). Although frozen concentrates of starter cultures are widely used in the production of fermented foods, there is a market for dried starter cultures. Commercial production of spray-dried starters has not been widely successful because cells of many bacterial strains are killed by spray drying. A better understanding of the causes of cell injury by drying would be useful to prevent such death and to produce dried cultures with high viability.

A serious problem of shelf-life stability with dried cultures has been presented in the literature. Even though the dried cultures are often kept under refrigeration they have objectionably short shelf-lives. Without refrigeration the dried cultures are rapidly inactivated (Higginbottom 1953; Foster 1962; Porubcan and Sellers 1975 ; Teixeira et al. 1995b).

Flavour changes in dry products during storage are mainly due to the lipid oxidation (Min et al. 1990). During food storage, unsaturated acyl lipids such as oleic acid cannot be considered as stable food constituents. They have one or

Correspondence 10: Dr Roy Kirby, Escola Superior de Biolecnologia, Unizersidade Catolica Portuguesa, R. Dr Antómio Bermardino de Almeida, +200 Porto, Portugal. more allyl groups within the fatty acid molecule and thus are readily oxidized to hydroperoxides.

ESR spectroscopic studies showed that food drying itself promoted the formation of free radicals which might initiate lipid peroxidation (Belitz and Grosch 1987). The mechanisms of death during storage of dried bacterial cell concentrates are still unknown; however, evidence is presented in the literature suggesting that lipid oxidation and survival during storage may be related (Dimmick and Heckly 1961 ; Marshall et al. 1974 ; Porubcan and Sellers 1975 ; Teixeira et al. 1995b). Cytoplasmic membrane damage has been reported for lactic acid bacteria following drying and subsequent storage (Brennan et al. 1986; Lievense et al. 1994; Teixeira et al. 1995b). Membrane fatty acids analyses of dried cells of Lactobacillus bulgaricus were performed during storage in air in order to try to detect some evidence of membrane lipid oxidation.

\section{MATERIALS AND METHODS}

\section{Organism}

Lactobacillus delbrueckii subsp. bulgaricus NCFB 1489 was used. The original reference cultures were maintained in cryogenic storage at $-80^{\circ} \mathrm{C}$ on glass beads. Working cultures were grown on De Man, Rogosa, Sharp (MRS) (Lab M, Bury, UK) broth containing $1.5 \%$ agar (MRSa) as slope cultures $\left(37^{\circ} \mathrm{C}\right.$ for $\left.24 \mathrm{~h}\right)$. Slopes were stored at $4^{\circ} \mathrm{C}$ and subcultured every month. New working cultures were prepared from the original reference culture every third month. 


\section{Preparation of cultures}

MRS broth was inoculated from the MRSa slopes and incubated for $24 \mathrm{~h}$ at $42^{\circ} \mathrm{C}$. This broth was then used to inoculate 11 of a second MRS broth $(1 \%, v / v)$. The cultures were incubated at $42^{\circ} \mathrm{C}$ for $24 \mathrm{~h}$ and agitated using magnetic stirrer bars. Cells were harvested by centrifugation at $10000 \mathrm{~g}$ for $10 \min \left(4^{\circ} \mathrm{C}\right)$.

\section{Preparation of media}

Unless otherwise stated, all media and buffers were prepared using deionized water and sterilized by autoclaving for 15 $\min$ at $121^{\circ} \mathrm{C}$.

The diluent phosphate buffer contained $0.01 \mathrm{~mol}^{-1}$ $\mathrm{K}_{2} \mathrm{HPO}_{+}, 0.01 \mathrm{~mol} \mathrm{l}^{-1} \mathrm{KH}_{2} \mathrm{PO}_{+}$, and $0.15 \mathrm{~mol} \mathrm{l}^{-1} \mathrm{NaCl}$ (Merck, Frankfurt, Germany), adjusted to $\mathrm{pH} 7 \cdot 0 \pm 0 \cdot 1$, and sterilized.

The medium used for plate count enumeration was MRSa. The MRS was prepared according to the manufacturer's instructions, and $15 \mathrm{~g} \mathrm{l}^{-1}$ of technical agar no. 3 (Lab M) were then added. The medium was sterilized and then cooled to $55^{\circ} \mathrm{C}$ before distribution into Petri dishes or bottles.

\section{Spray drying}

Skim milk (Lab M) was inoculated with cells previously grown to stationary phase in MRS at a ratio of $1: 1(\mathrm{v} / \mathrm{v})$. The milk was incubated under constant stirring for $30 \mathrm{~min}$ at $37^{\circ} \mathrm{C}$ to allow for cell adaptation, and then samples were sprayed in a laboratory-scale spray drier (Niro Atomizer, Gladsaxevej, Denmark) using a vaned wheel rotating at high speed. The moisture in the droplets thus formed was reduced via evaporation in a vertical, cocurrent drying chamber $(0 \cdot 8$ $\mathrm{m}$ diam. and $0.6 \mathrm{~m}$ height). The air temperatures at the inlet and outlet of the spray drier were set to $200^{\circ} \mathrm{C}$ and $70^{\circ} \mathrm{C}$, respectively. The powder was collected in a single cyclone separator. Samples of the spray-dried inoculum were stored at $20^{\circ} \mathrm{C}$ in hermetically-sealed glass bottles in which the water activity was controlled by equilibration with a saturated aqueous solution of $\mathrm{LiCl}$ (Merck) to give a value of $0 \cdot 11$.

\section{Enumeration of micro-organisms}

At regular intervals during storage, spray-dried samples were rehydrated to the original volume with deionized water at $20^{\circ} \mathrm{C}$, and suitable dilutions were plated on agar plates by the drop count technique (Miles and Misra 1938). These plates were incubated under aerobic conditions at $37^{\circ} \mathrm{C}$ for $48 \mathrm{~h}$, and survival rates were estimated.

\section{Fatty acids analysis by gas-liquid chromatography (GLC)}

Sample preparation. One $\mathrm{ml}$ of normal or dried-rehydrated cellular suspensions were harvested and washed with sterile deionized water at $5000 \mathrm{~g}$ for $10 \mathrm{~min}$ at room temperature. Bacterial fatty acid analysis was done according to Rozes $e t$ al. (1993).

Extraction and methylation of fatty acids. Methanolysis of cell materials was carried out with sodium methoxide in methanol. Heneicosanoic acid methyl ester was used as internal standard. Sodium methoxide $(0.5 \mathrm{ml})\left(1 \mathrm{~mol} \mathrm{l}^{-1}\right)$ was added in a glass stoppered tube containing the cell pellets. The tube was mixed for $1 \mathrm{~min}$ and then fatty acids methyl esters were extracted by shaking with $0.3 \mathrm{ml}$ of hexane for $20 \mathrm{~s}$. The upper phase was removed after decanting and $1 \mu \mathrm{l}$ was injected onto the chromatograph.

Gas-liquid chromatography. Analytical GLC was carried out on a Hewlett Packard 5890 (Palo Alto, USA) equipped with a flame ionization detector and connected to a Hewlett Packard integrator (3393A). The following operating conditions were used: Chrompack (Herts, The Netherlands) capillary column, (Wcot 7485) fused silica $(25 \mathrm{~m} \times 0.32 \mathrm{~mm} \times 0.3 \mu \mathrm{m})$;

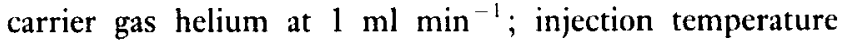
$250^{\circ} \mathrm{C}$; detection temperature $250^{\circ} \mathrm{C}$, oven temperature initially $80^{\circ} \mathrm{C}$, rising to $220^{\circ} \mathrm{C}$ at $3^{\circ} \mathrm{C} \mathrm{min}{ }^{-1}$, splitless for $30 \mathrm{~s}$; sample size $1 \mu \mathrm{l}$.

The total of the areas of the chromatogram peaks of the main fatty acids was considered as the total amount of fatty acids since they represent about $82 \%$ of the total fatty acids present in Lact. bulgaricus (Goldberg and Eschar 1977). The areas of the individual peaks were used to determine the relative percentage of each fatty acid present, and calculation of the ratio unsaturated to saturated fatty acids.

\section{Statistical analysis}

The hypothesis that the ratios unsaturated/saturated fatty acids before and after drying were different was tested against the null hypothesis using a classical $t$-test (Box et al. 1978). Significance was declared at $P<0.05$. During storage, for the ratio unsaturated/saturated fatty acids the normality of the residuals of each set of three replicates with respect to their mean, and the independence of the estimated variances vs the corresponding mean were tested. No significant bias was detected. Data were analysed via the ANOVA methodology using the Statview ${ }^{\mathrm{TI}}$ package (Abacus Concepts, Berkeley, CA) using as independent variable the storage time. 


\section{RESULTS AND DISCUSSION}

Spray drying resulted in cytoplasmic membrane damage in Lact. bulgaricus as evidenced by increased sensitivity of dried cells to $\mathrm{NaCl}$ and increased leakage of potassium ions and $\beta$ galactosidase in the supernatant fluids (Teixeira et al. 1995a). Since permeability control is mainly associated with cell membrane, the phenomena of leakage and increased salt sensitivity suggested that the cellular defects responsible were located in the cell envelope. Since membrane lipids play an important role in cytoplasmic membrane permeability, assuming that a large portion of the cellular fatty acids are present in the membrane, it seemed probable that membrane damage in the dried cells was reflected in, or caused by, changes in the lipid profile.

The ratio of unsaturated/saturated fatty acids decreased, compared to normal control cells (Table 1), indicating that spray drying induces lesions in the cellular lipid-containing structure(s).

Similar results were obtained by Duitschaever and Jordan (1974) during recovery of heat-injured Streptococcus faecium. Brennan et al. (1986) did not find significant differences in the fatty acids of normal and freeze or vacuum-dried Lactobacillus acidophilus cells.

In't Veld et al. (1992) reported that the degree of unsaturation of lipids has a marked effect on the permeability of the membrane. It is possible, therefore, that increased permeability of spray-dried cells to the compounds mentioned above, may be due to changes in the membrane lipids profile.

Experiments performed in this work were carried out in order to determine if changes in the lipid profile occurred during storage of dried Lact. bulgaricus. The ratio of unsaturated/saturated fatty acids decreased during storage (Table 2) presenting evidence of lipid oxidation (Slater 1984; Takiguchi 1987). This decrease, however, was significant $(P<0.05)$ only after $49 \mathrm{~d}$ of storage. In foods, the initial oxidation products are detectable only after a certain elapsed storage time; this stage is termed the induction period (de
Man 1990). When this incubation period, which is typical for a given autoxidation process, has expired, a steep rise occurs in the reaction rate (Belitz and Grosch 1987). It is possible that a similar mechanism might be responsible for the changes in the ratio of unsaturated/saturated fatty acids of dried cells occurring during storage.

Figure 1 shows the relation between changes in the unsaturated/saturated fatty acids and survival of dried Lact. bulgaricus during storage. During the first $49 \mathrm{~d}$ of storage while no significant changes in the ratio unsaturated/saturated fatty acids were detected, probably for the reason outlined above, survival decreased. Following this period the decrease in the ratio unsaturated/saturated fatty acids and cell death occurred essentially at the same rate. As stated before, the mechanisms of death during storage are still unknown but from these results it seems evident that lipid oxidation and survival during storage may be related. This is supported by indirect evidence presented in previous reports. For example, it is reported that the presence of antioxidants increased the survival rate of dried bacteria during storage (Porubcan and Sellers 1975; Teixeira et al. 1995b). Dimmick and Heckly (1961) found a strong similarity between the loss of viability and the increase in free-radical concentration during storage of freeze-dried Serratia marcescens. Work done by Marshall et al. (1974) supports the hypothesis that reactions between carbonyl compounds and cellular components are a major cause of mortality during storage of dried micro-organisms. The nature of these compounds was not presented but it is possible that they are products formed during lipid oxidation. Slater (1984) reported that, in eukaryotic cells, extensive lipid peroxidation can result in membrane disorganization by peroxidizing mainly the highly unsaturated fatty acids leading to changes in the ratio of unsaturated to other fatty acids. The uncontrolled peroxidation of biomembranes can thus lead to profound effects on membrane structure and function, and may be sufficient to cause cell death.

Lipid peroxidation may also be involved in DNA damage.

Table 1 Fatty acid composition of normal and spray-dried Lactobacillus bulgaricus

\begin{tabular}{|c|c|c|c|c|c|c|c|}
\hline & \multicolumn{5}{|c|}{ Relative percentages in fatty acids } & \multirow[b]{2}{*}{ Uns/Sat } & \multirow[b]{2}{*}{$\log \mathrm{cfu} \mathrm{ml}{ }^{-}$} \\
\hline & $16: 0$ & $16: 1$ & $18: 0$ & $18: 1$ & $\Delta 19: 0$ & & \\
\hline Before drying & $\begin{array}{l}6.28 \\
(0.95)^{*}\end{array}$ & $\begin{array}{l}30 \cdot 44 \\
(1 \cdot 03)\end{array}$ & $\begin{array}{l}0.72 \\
(0.24)\end{array}$ & $\begin{array}{l}35.39 \\
(1.77)\end{array}$ & $\begin{array}{l}27 \cdot 17 \\
(1 \cdot 74)\end{array}$ & $13 \cdot 29+$ & $8 \cdot 81$ \\
\hline After drying & $\begin{array}{l}10 \cdot 41 \\
(2.03)\end{array}$ & $\begin{array}{l}27.99 \\
(0.94)\end{array}$ & $\begin{array}{l}2 \cdot 35 \\
(0 \cdot 90)\end{array}$ & $\begin{array}{l}34 \cdot 26 \\
(2 \cdot 21)\end{array}$ & $\begin{array}{l}25 \cdot 00 \\
(3 \cdot 28)\end{array}$ & $6.84 t$ & 7.95 \\
\hline
\end{tabular}

\footnotetext{
* Standard deviation.
}

t+ Means with different superscripts in the same column are statistically different $(P<0.05)$. Average of four experiments. Fatty acid methyl esters are designated by the number of carbon atoms to the left of the colon, and number of double bonds to the right.

$\Delta 19: 0$ denotes a 19 carbon cyclopropane fatty acid. 
Table 2 Fatty acid composition of spraydried Lactobacillus bulgaricus during storage
Relative percentages in fatty acids

\begin{tabular}{|c|c|c|c|c|c|c|}
\hline \multirow[b]{2}{*}{ Time (d) } & \multicolumn{5}{|c|}{ Relative percentages in fatty acids } & \multirow[b]{2}{*}{ Uns/Sat } \\
\hline & $16: 0^{\mathrm{a}}$ & $16: 1$ & $18: 0$ & $18: 1$ & $\Delta 19: 0$ & \\
\hline 0 & $\begin{array}{l}10 \cdot 41 \\
(2 \cdot 03)^{*}\end{array}$ & $\begin{array}{l}27.99 \\
(0.94)\end{array}$ & $\begin{array}{l}2 \cdot 35 \\
(0.90)\end{array}$ & $\begin{array}{l}34 \cdot 26 \\
(2 \cdot 21)\end{array}$ & $\begin{array}{l}25 \cdot 00 \\
(3 \cdot 28)\end{array}$ & $6.84 \dagger$ \\
\hline 32 & $\begin{array}{l}10.63 \\
(2 \cdot 83)\end{array}$ & $\begin{array}{l}25 \cdot 8 \\
(2 \cdot 56)\end{array}$ & $\begin{array}{l}2 \cdot 42 \\
(0 \cdot 44)\end{array}$ & $\begin{array}{l}35.46 \\
(1.67)\end{array}$ & $\begin{array}{l}25 \cdot 72 \\
(2 \cdot 42)\end{array}$ & $6.67 \uparrow$ \\
\hline 49 & $\begin{array}{r}9 \cdot 54 \\
(2 \cdot 40)\end{array}$ & $\begin{array}{l}30 \cdot 46 \\
(3 \cdot 75)\end{array}$ & $\begin{array}{l}3.46 \\
(0.61)\end{array}$ & $\begin{array}{l}34.08 \\
(5.05)\end{array}$ & $\begin{array}{l}21 \cdot 9 \\
(2 \cdot+7)\end{array}$ & $6.64 \dagger$ \\
\hline 75 & $\begin{array}{l}12 \cdot 18 \\
(0 \cdot 76)\end{array}$ & $\begin{array}{l}23 \cdot 32 \\
(4 \cdot 43)\end{array}$ & $\begin{array}{l}5.65 \\
(0.99)\end{array}$ & $\begin{array}{l}34 \cdot 36 \\
(1 \cdot 12)\end{array}$ & $\begin{array}{l}24.97 \\
(0.89)\end{array}$ & $4.64 t$ \\
\hline 96 & $\begin{array}{l}15 \cdot 70 \\
(2 \cdot 98)\end{array}$ & $\begin{array}{l}19 \cdot 87 \\
(0 \cdot 28)\end{array}$ & $\begin{array}{l}10 \cdot 83 \\
(1 \cdot 11)\end{array}$ & $\begin{array}{l}32 \cdot 43 \\
(0.96)\end{array}$ & $\begin{array}{l}21 \cdot 04 \\
(5 \cdot 54)\end{array}$ & $2 \cdot 76 \S$ \\
\hline SEM & & & & & & $1 \cdot 19$ \\
\hline
\end{tabular}

* Standard deviation.

$\dagger \downarrow$ Means with different superscripts in the same column are statistically different $(P<0.05)$. Fatty acid methyl esters are designated by the number of carbon atoms to the left of the colon, and number of double bonds to the right. $\Delta 19: 0$ denotes a 19 carbon cyclopropane fatty acid.
Products of lipid peroxidation have been shown to induce DNA damage in model systems (Inouye 1984; Akasaka 1986) and in bacteria (Marnett et al. 1985). Akasaka and Yonei (1985) have reported that incubation of Escherichia coli with peroxidizing rat liver microsomes induces mutation and that the mutation frequency correlates well with the extent of lipid peroxidation. Lipid peroxidation has also been implicated in various stages of carcinogenesis (Cheeseman 1993). This implies that DNA damage may occur as a result of lipid peroxidation in vivo. In isolated systems such as liver nuclei, mitochondria and liver slices, DNA damage was detected when lipid peroxidation was induced (Shires 1982; Fraga and

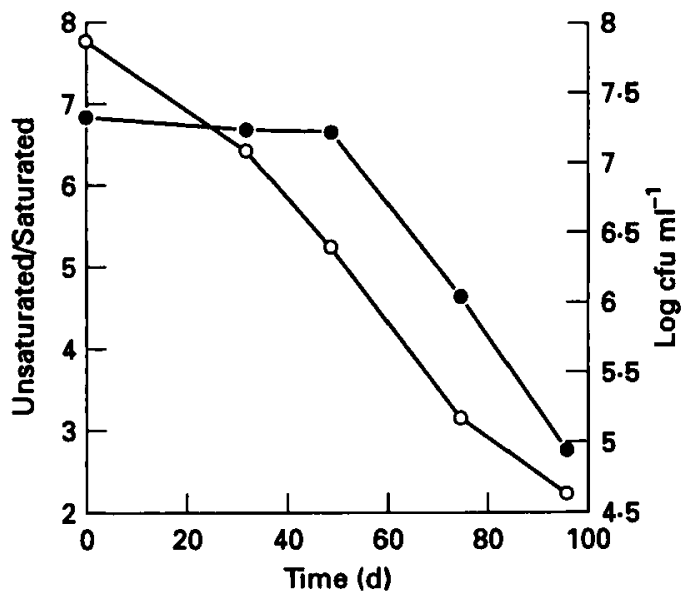

Fig. 1 Survival $(O)$ and ratio unsaturated/saturated lipids $(O)$ of spray-dried Lactobacillus bulgaricus during storage at $20^{\circ} \mathrm{C}$ and $0 \cdot 11$ water activity.
Tappel 1988; Hruszkewycz and Bergtold 1990). The nature of the DNA-damaging species has not been determined. Peroxyl and alkoxyl radicals, which may be generated by reactions of iron ion complexes with lipid hydroperoxides (Halliwell and Gutteridge 1989) and some other products of lipid peroxidation such as reactive carbonyl products, possess diffusibility and are possible mutagens (Esterbauer et al. 1990; Cheeseman 1993). Although cellular repair enzymes are available to repair several kinds of DNA damage, there is always a probability of misrepair. This may lead to altered cellular function or, if the damage is at a critical point, death (Floyd 1990).

\section{REFERENCES}

Akasaka, S. (1986) Inactivation of transforming activity of plasmid DNA by lipid peroxidation. Biochimica et Biophysica Acta 867, 201-208.

Akasaka, S. and Yonei, S. (1985) Mutation induction in Escherichia coli incubated in the reaction mixture of NADPH-dependent lipid peroxidation of rat-liver microsomes. Mutation Research 149, 321-326.

Belitz, H.D. and Grosch, W. (1987) Food Chemistry. Berlin : Springer Verlag.

Box, G.E.P., Hunter, W.G. and Hunter, J.S. (1978) Statistics for Experiments. An Introduction to Design, Data Analysis, and Model Building. New York: John Wilcy.

Brennan, M., Wanismail, B., Johnson, M.C. and Ray, B. (1986) Cellular damage in dried Lactobacillus acidophilus. Journal of Food Protection 49, 47-53.

Cheeseman, K.H. (1993) DNA and Free Radicals. New York: Ellis Horwood. 
de Man, J.M. (1990) Principles of Food Chemistry. New York: AVI Book.

Dimmick, R.L. and Heckly, R.J. (1961) Free radical formation during storage of freeze dried Serratia marcescens. Nature 192, 776 .

Duitschaever, C.L. and Jordan, D.C. (1974) Development of resistance to heat and sodium chloride in Streptococcus faecium recovering from thermal injury. Journal of Milk and Food Technology 37, 382-386.

Esterbauer, H., Eckl, P. and Ortner, A. (1990) Possible mutagens derived from lipids and lipid precursors. Mutation Research 238, 223-233.

Floyd, R.A. (1990) Role of oxygen free radicals in carcinogenesis and brain ischemia. FASEB fournal 4, 2578-2579.

Foster, E.M. (1962) Culture preservation. Journal of Dairy Science 45, 1290-1294.

Fraga, C.G. and Tappel, A.L. (1988) Damage to DNA concurrent with liver peroxidation in rat liver slices. Biochemical fournal 252, 89.3-896.

Gilliland, S.E. (1976) Preparation and storage of concentrated cultures of lactic streptococci. Journal of Dairy Science 60, 805-809.

Goldberg, I. and Eschar, L. (1977) Stability of lactic acid bacteria to freezing as related to their fatty acid composition. Applied and Environmental Microbiology 33, 489-496.

Halliwell, B. and Gutteridge, J.M.C. (1989) Free Radicals in Biology and Medicine. Oxford : Clarendon Press.

Higginbottom, C. (1953) The effect of storage at different relative humidities on the survival of microorganisms in milk powder and in pure cultures dried in milk. Journal af Dairy Research 20, 65.

Hruszkewycz, A.M. and Bergtold, D. (1990) The 8-hydroxyguanine content of isolated mitochondria increases with lipid peroxidation. Mutation Research 244, 123-128.

Inouye, S. (1984) Site-specific cleavage of double-stranded DNA by hydroperoxide of linoleic acid. FEBS Letters 172, 231-234.

In't Veld, G., Driessen, A.J.M. and Konings, W.N. (1992) Effect of the unsaturation of phospholipid acyl chains on leucine trans- port of Lactococcus lactis and membrane permeability. Biochimica et Biophysica Acta 1108, 31-39.

Lievense, L.C., Verbeek, M.A.M., Ad Noomen, and van't Riet, K. (1994) Mechanism of dehydration inactivation of Lactobacillus plantarum. Applied Microbiology and Biotechnology' 41, 90-94.

Marnett, L.J., Hurd, H.K., Hollstein, M.C., Levin, D.E., Esterbauer, H. and Ames, B.N. (1985) Naturally occurring carbonyl compounds are mutagens in Salmonella tester strain TA 104. Mutation Research 148, 25-34.

Marshall, B.J., Coote, G.G. and Scott, W.J. (1974) A study of factors affecting the survival of dried bacteria during storage. CSIRO Australian Division of Food Research, Technical Paper 39, $1-29$.

Miles, A.A. and Misra, S.S. (1938) The estimation of the bactericidal power of blood. Fournal of Hygiene (Cambridge) 38, 732-749.

Min, D.B., Ticknor, D.B., Lee, S.H. and Reineccius, G.A. (1990) Effects of processing conditions and antioxidants on the oxidative stability and carbon dioxide formation in low fat dry milk. Journal of Food Science 55, 401-403.

Porubcan, R.S. and Sellers, R.L. (1975) Stabilized dry cultures of lactic acid producing bacteria. US Patent 3897307 , July 9.

Rozes, N., Garbay, S., Denayrolles, M. and Lonvaud-Funel, A. (1993) A rapid method for the determination of bacterial fatty acid composition. Letters in Applied Microbiology 17, 126-131.

Shires, T.K. (1982) Iron-induced damage and synthesis in isolated rat liver nuclei. Biochemical fournal 205, 321-329.

Slater, T.F. (1984) Free-radical mechanism in tissue injury. Biochemical fournal 222, 1-15.

Takiguchi, A. (1987) Lipid oxidation and hydrolysis in dried anchovy products during drying and storage. Bulletin of the Japanese Society of Scientific Fisheries 53, 1463-1469.

Teixeira, P., Castro, H. and Kirby, R. (1995a) Spray drying as a method for preparing concentrated cultures of Lactobacillus bulgaricus. Journal of Applied Bacteriology 78, 456-462.

Teixeira, P., Castro, H. and Kirby, R. (1995b) Survival of Lactobacillus delbrueckii ssp. bulgaricus following spray drying. fournal of Dairy Science 78 (in press). 